\title{
Selecting an Initial Lemma List in Specialized Lexicography: A Case Study in the Field of Graphic Engineering
}

M.A. Esandi-Baztan, Department of Materials Science and Metallurgical Engineering, Graphic Expression in Engineering, Cartographic Engineering, Geodesy and Photogrammetry, Mechanical Engineering and Manufacturing

Process Engineering, Universidad de Valladolid, Spain

(mariaangeles.esandi@uva.es)

and

Pedro A. Fuertes-Olivera, Department of Afrikaans and Dutch, University of Stellenbosch, South Africa and International Centre for Lexicography,

Universidad de Valladolid, Valladolid, Spain (pedro@emp.uva.es)

\begin{abstract}
Specialized lexicography in graphic engineering has never had a tool in dictionary format that facilitates knowledge acquisition for students and meets their specific lexicographic needs in a technical university context. This paper presents an initial lemma list for a Spanish dictionary in the field of graphic engineering. The Delphi method has been used to assure expert consensus in this area. In addition, two equally professional surveys have been conducted by an expert and endorsed by experts. The fundamental concepts are considered, either because of the difficulty they represent, or due to their importance within our field of knowledge for which engineering documents and technical standards with technical graphic elements have been employed. Students have taken part in the process, thereby allowing identification of convergences and divergences between both groups of participants. The paper concludes with, on the one hand, a final list of accepted concepts and, on the other, of additional uncertain concepts, which could satisfy dictionary user needs and constitute the beginning of a functional online dictionary.
\end{abstract}

Keywords: SPECIALIZED LEXICOGRAPHY, FUNCTIONAL ONLINE DICTIONARY, DELPHI METHOD, USER NEEDS, EXPERT CONSENSUS, GRAPHIC ENGINEERING, PERCEIVED CONCEPT DIFFICULTY, PRIOR KNOWLEDGE

Opsomming: Die selektering van 'n aanvanklike lemmalys in gespesialiseerde leksikografie: 'n Gevallestudie in die veld van die grafiese ingenieurswese. Gespesialiseerde leksikografie in die grafiese ingenieurswese het nog nooit oor 'n hulpmiddel in woordeboekformaat wat kennisverwerwing vir studente vergemaklik asook hul spesifieke leksikografiese behoeftes binne 'n tegniese konteks op universiteitsvlak bevredig, beskik nie. Hierdie artikel bied ' $n$ aanvanklike lemmalys vir 'n Spaanse woordeboek in die veld van die grafiese ingenieurswese aan. Die Delphi-metode is gebruik om gesaghebbende konsensus in hierdie area te verseker. Daarbenewens is twee gelykstaande professionele opnames deur ' $n$ kundige uitgevoer en 
deur kundiges bekragtig. Die fundamentele konsepte is oorweeg, óf weens die uitdagings wat hulle verteenwoordig, óf weens hul belangrikheid binne ons kennisveld waarvoor ingenieursdokumente en tegniese standaarde met tegniese grafiese elemente aangewend is. Studente het aan die proses deelgeneem om sodoende ooreenkomste en verskille tussen beide groepe deelnemers in aanmerking te neem. Hierdie artikel sluit enersyds af met 'n finale lys aanvaarde konsepte en andersyds met 'n lys addisionele vae konsepte wat woordeboekgebruikers se behoeftes sou kon bevredig en die ontstaan van 'n funksionele aanlyn woordeboek sou kon vorm.

Sleutelwoorde: GESPESIALISEERDE LEKSIKOGRAFIE, FUNKSIONELE AANLYN WOORDEBOEK, DELPHI-METODE, GEBRUIKERSBEHOEFTES, GESAGHEBBENDE KONSENSUS, GRAFIESE INGENIEURSWESE, WAARGENOME MOEILIKHEIDSGRAAD VAN KONSEPTE, VOORAFKENNIS

\section{Introduction}

This article discusses some of the main issues involved in a lexicographic project. Firstly, it aims at conceptualizing an online dictionary targeting Spanish students of graphic expression in engineering. Secondly, it presents the basics of research that has "used" experts to select the main and initial lemma list of the dictionary project and submit their proposal to further scrutiny by the potential beneficiaries, Spanish students of graphic expression in engineering.

The project is based on the tenets of the Function Theory of Lexicography (Bergenholtz and Tarp 2003; Fuertes-Olivera and Tarp 2014; Tarp 2008), adding to its main assumptions a major degree of adaptation to meet potential users' needs. In this way, we will show how the presentation and representation of knowledge in the field of Graphic Engineering can be enhanced with the joint participation of experts and students.

Fuertes-Olivera and Bergenholtz (2011), among others, have analyzed some of the changes and challenges brought about by the internet, especially those concerned with lexicographic tasks in production and reception situations. It is true that the internet facilitates the conception and dynamic development of a dictionary as well as the immediate and simultaneous access of an unlimited number of users to lexicographic and extra-lexicographic data. It is possible to update an online dictionary as there is the advantage of its being flexible, dynamic and extensible (Pinnis et al. 2013: 123), resulting in new possibilities for the representation of specialized lexicography. The social and personal use of information and communication technologies enables and supports the initiatives of this representation on devices such as computers, mobile phones and tablets, indicating new patterns in the use of dictionaries.

The data in an online dictionary can be updated and extended and its articles (dictionary entries) allow a customized access and retrieval of information. It must allow for a specific type of information and present a specific selection of lexicographically treated data conditioned by the user's needs (Fuertes-Olivera and Bergenholtz 2018: 191). An appropriate methodology enables immediate 
access to data (adding and storing), the content of which is adapted to use situations. As Tarp states, "The traditional dictionary articles with static data and fixed structures should be replaced by articles containing dynamic data which are, so to say, unique for each search related to a specific type of user in a specific type of user situation" (Tarp 2009: 29). We agree that access to lexicographic and multimedia data presented should satisfy those needs within an acceptably short time and with the required degree of detail and the data must be presented in a form that is maximally comprehensible.

In the domain of graphic expression in engineering, data are either scant or difficult to distinguish and systematize. To the best of our knowledge, there are no reference works in this field of knowledge. Hence, we have resorted to novel methods and methodologies for preparing an initial lemma list representative of this field and allowing for enlargement. As shown below, we have used the Delphi method to start our project. This consists of initiating a consensus process by a panel of experts in this area; these are responsible for developing a Concept inventory for Engineering Graphics, e.g. the method used by Sadowski and Sorby (2015), who pioneered the use of this technique to produce such an inventory. The results obtained, in the present study, will be then reevaluated by experts and students so as to analyze more focused objectives, i.e. the ones with which our students are more familiar and in greater need of assistance. In fields such as business (Czinkota and Ronkainen 1997), engineering (Hallowell and Gambatese 2010) and medicine (Flume et al. 2010) there are numerous studies that use this technique to formalize the consensus process of a panel of experts and to develop explicit recommendations for a majority of people, but adaptable to the specific needs of individuals.

Graphic communication in engineering involves using visual material to relate ideas. A drawing is a form of graphic communication that represents an idea, a concept or an entity which actually or potentially exists in life (Goetsch, Chalk and Nelson 2000). The domain of graphic engineering requires a complex cognitive process and the conceptual system that assists certain mental operations in this domain is also complex (Kageura 1997: 119). In this paper, we aim to demonstrate that it is possible to make this conceptual system accessible via a lexicographic tool, and to show the characteristics of its lexicographic representation. We must first identify the concepts that best fit our objectives, establish the structure and content of each concept, and verify whether the Delphi method used in its selection is a success. In each case, we make a proposal for a definition that helps to disambiguate the concept, that is, to determine the meaning of the concept in the context. The consensus opinion of a panel of experts minimizes subjectivity, whilst allowing us to draw up a list of concepts avoiding systematic errors, and define the lexicographic functions of the dictionary.

Section 2 deals with lemma selection in dictionaries, the influence of the use of corpora and other recommended methods in specialized lexicography, the modified Delphi method and the influence of the sources used. We show, 
in section 3, the results acquired in two rounds with experts (as an example of analysis to support the strategy based on the experience and consensus of a group of experts) and one extra round with students. Section 4 focuses on the discussion and analysis of the data, a proposal for concept definition and data structure of an initial lemma list, together with the convergences and divergences between students and experts. Finally, the conclusion (section 5) attempts to indicate the practical implications of this project and future research.

\section{Material and methods}

Following the principles of the Functional Theory of Lexicography and the reasoning of the deductive method, the process begins by focusing on the user of the dictionary, their situation and their needs. Once these premises have been identified, the nature of the field of specialized knowledge conditions its lexicographic treatment.

A review of the literature on lemma selection processes indicates that there are four main methods for selecting the lemma list of a new dictionary project: (a) existing dictionaries; (b) grammar and etymology; (c) canonical texts (e.g. lemmas must be selected from literary works); and (d) corpora. Authors such as Bowker and Pearson (2002), Čermák (2003), Pérez Hernández, Moreno Ortiz and Faber Benítez (1999), among others, have analyzed the advantages and disadvantages of the different methods, including the choice of specialized terms. For instance, Verlinde and Selva (2009: 598) have studied corpus-based versus intuition-based lexicography, and have concluded that the former provides the lexicographer's personal intuition with important and necessary empirical evidence; however, intuition is still useful for filling the gaps that may occur in a corpus. In other words, the authors have called our attention to the necessity of submitting any process of lemma selection to a critical analysis, as each way of selecting has its pros and cons (see Fuertes-Olivera and Tarp 2014 for a review of this issue). Following this line of thought, we have used a different method for selecting the initial lemma list of our project, namely, the Delphi method.

\subsection{The Delphi method}

The Delphi method (Linstone and Turoff 1975) consists of structuring the communication process of a group of experts who function as a set. The group is comprised of a selected panel whose opinion is sought via successive strategically designed surveys. We are interested in the fundamental concepts considered, either because of the difficulty they present, or because of their importance within the field of knowledge and our field of action. The method allows us to identify convergences of opinions and predicts provisional consensus in order to finally determine and quantify the consensus of the group. It is possible to use both quantitative techniques (Rowe and Wright 1999) and 
qualitative ones when we are interested in the interpretation, understanding and experimentation of the social context within which the data are collected, resulting in a holistic understanding of the latter (Mason 1996). Qualitative research should be carried out strategically but in a flexible and contextual way (Mason 2002: 7) so as to obtain highly reliable data from, in our case, reputable experts.

There are two distinct methods of the Delphi process: the paper-and-pencil version known as "Delphi Exercise" or conventional Delphi and the "Delphi Conference" or the real-lucre Delphi version (Linstone and Turoff 1975: 5). The differences between the two lie in the use of a physical or computer support, and in that of software for data analysis in the second case. The latter allows, in real time, the drawing-up of a new questionnaire addressed to the group, but requires that the characteristics of the communication be defined before the Delphi process begins. However, in a Delphi exercise with "paper and pencil" these characteristics can be adjusted for the next round, depending on the answers obtained in the previous session. In essence, the Delphi technique consists of a series of sequential questionnaires interspersed by controlled feedback used to obtain the consensus of opinion from a panel of experts (Powell 2003: 377).

\subsubsection{Process}

We focus on the expert method endorsed by experts, with, therefore, an expert who designs the questionnaires that are sent to a group of fellow professionals. To carry out this work, we have informants chosen among professional professors, from the graphic expression in engineering ( $E G I)$ area of knowledge, to identify the fundamental concepts, and student informants of an engineering school (Escuela de Ingenierías Industriales at the University of Valladolid). The members of the panel of experts are five full-time professors (from a set of ten) in the field of EGI at the University of Valladolid. They were selected on the basis of their long experience in EGI (between 26 and 40 years) in subjects such as Metric Geometry, Representation Systems, Technical Drawing and Computer-Aided Design and Technical Drawing in industrial engineering degrees.

The first panel of experts' contact is a semi-structured "brainstorm", in which our research topic is set out whilst considering other topics related to the fields of knowledge of this research, namely, Lexicography (specifically with the Function Theory of Lexicography) and the EGI. The contribution to the debate by the members of the group was enriching and comprehensive; it was recognized that an online dictionary would represent a real opportunity for students, due to their needs and their familiarity with digital devices.

Two rounds were carried out with feedback on the results and the paperand-pencil option was employed. Once the first paper questionnaire had been completed, it was returned and the results were analyzed so that the necessary adjustments could be made depending on the comments received. In accordance with the results and contributions, a second questionnaire was prepared 
based on the assessment of the group response, and the panellists had the chance to re-evaluate their own answers in light of group responses. The Delphi method was modified by including, in the second round, not only the concepts identified by our experts but also some of those identified in the study conducted by Sadowski and Sorby (2015) on graphic engineering. We accordingly considered and evaluated the impact of all of these items.

\subsubsection{Material}

The questionnaires are derived from two compendia of practices used in the student learning process, namely, a theoretical manual on representation systems and the standard document on the general principles of presentation in technical drawings. The participants were familiar with the internship documents, three of them being, in fact, co-authors of the 2018 collection. We considered it necessary to use a standard as a resource since this involves published recommendations which provide communicative facts. The resources for the round I questionnaire statements were as follows:

- Nieto Oñate, M., V. González García and R. López Poza. 1970. Prácticas programadas de Dibujo Técnico. Delineantes industriales;

- Álvarez Garrote, S., E. Reboto Rodríguez, Q. Rodríguez Ovejero and M. Escribano Negueruela. 2018. Prácticas de Expresión Gráfica III;

- The standard UNE 1-032-82 (1982) corresponding to ISO 128;

- González García, V., R. López Poza and M. Nieto Oñate. 1982. Sistemas de representación. Sistema diédrico.

\subsubsection{Delphi process and questionnaire}

The Delphi process consisted of two rounds conducted with the panel of experts and a final evaluation. Questionnaire I was not structured, seeking an open answer (Powell 2003: 378) and, consisted of 111 statements $(12+22+64+13)$; respondents might firstly identify the relevant concepts and then assess, on a scale of 1 (little) to 5 (a great deal), the estimated importance and the difficulty foreseen for a semi-experienced student in the EGI at the university. In all the statements the participants were given the option to accept (respond), reject (not respond), provide comments and include the concepts they considered of interest and which do not appear in the statements. They were asked to identify, at their discretion, the concepts among the proposed statements, considering that the set consists of two parts, one verbal and one graphic. Regarding the four sources, the first two displayed identical characteristics: statements with a descriptive-informative verbalized statement and graphic support (a sample item is shown in Figure 1); for the statements corresponding to the UNE 1-032 (ISO 128) standard, the concepts (verbal and graphic) were previously identified at source and the standardized verbal denomination was used 
(see Figure 2). The fourth source corresponded to representation systems. In this case, the concepts were previously identified by an expert and were the result of decomposition into simple geometric constructions of complex ones, that is, the decomposition of complex concepts into simpler ones (see Figure 3). The constructions were analyzed individually, defined and gave rise to new unified and sometimes reformulated concepts; statements consisted of two parts, one verbal and one graphic. It should be noted that in these items the verbal component and the graphic component were equivalent, highlighting the expressiveness of the graphic component.

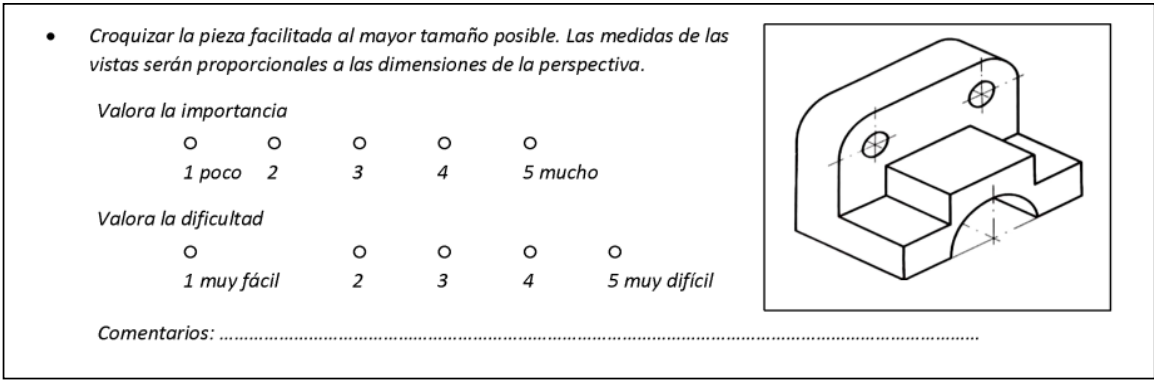

Figure 1: Example of a non-structured item with an open answer, with a verbal and graphic component (Source: Questionnaire I)

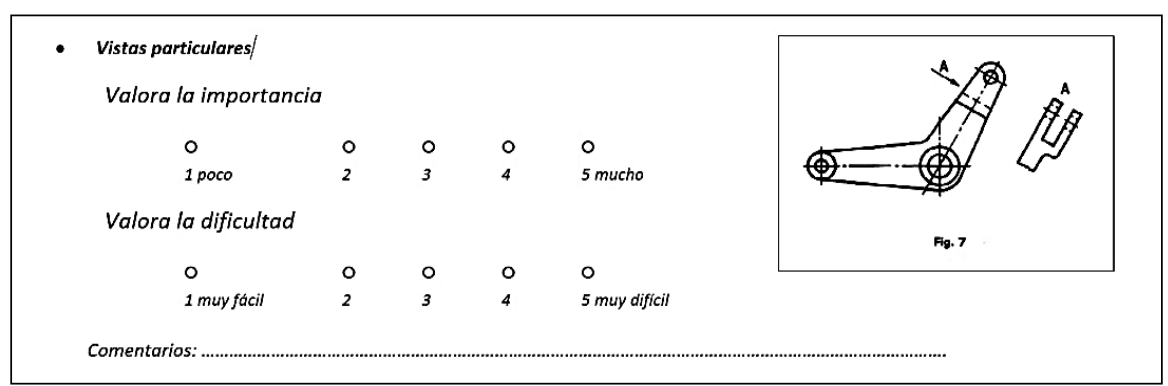

Figure 2: Example of concepts identified thanks to their graphic support (Source: UNE 1-032; ISO 128) 
Parte 3. La mínima distancia entre dos rectas que se cruzan, es la distancia de cualquier punto de la recta $s$ al plano $\pi$.

Valora la importancia

\begin{tabular}{|c|c|c|c|c|}
\hline \multicolumn{5}{|l|}{ Valora la importancia } \\
\hline 0 & o & 0 & 0 & 0 \\
\hline 1 poco & 2 & 3 & 4 & 5 mucho \\
\hline
\end{tabular}

Valora la dificultad

$\begin{array}{lllll}\circ & 0 & 0 & 0 & 0 \\ 1 \text { muyfácil } & 2 & 3 & 4 & 5 \text { muydificil }\end{array}$

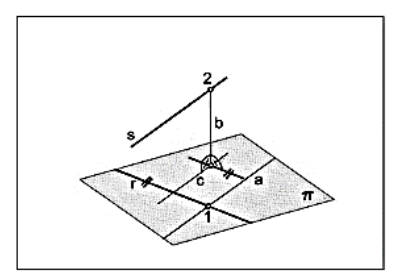

Comentarios:

Figure 3: Example of representational systems. Complex concepts are simplified (Own source)

In questionnaire II, items were specific, e.g. Figure 4, with the aim of having experts review and either confirm or not confirm the results of the first round. The results of questionnaire I allowed us to identify, relate and reformulate questionnaire II. The format avoided ambiguity in the statements so that the concepts identified by the expert informants were unambiguous and rigorous. There were 54 concepts previously identified and they were ranked in order from most to least important, being accepted by at least three experts; as we have already mentioned, 14 concepts from the aforementioned study by Sadowski and Sorby (2015) were also added.

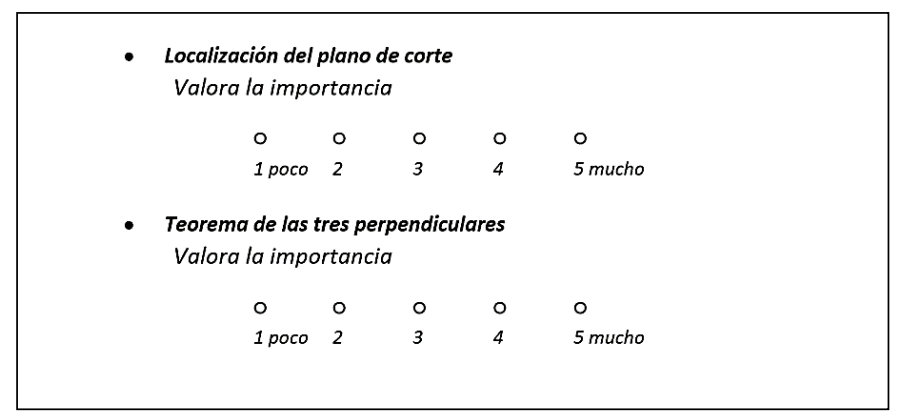

Figure 4: Example of a specific item without ambiguity (verbal component) (Own source)

\subsubsection{Administration of the questionnaire}

The questionnaire was delivered by hand at different moments and there was no communication between the members while the test was being carried out, 
thereby guaranteeing anonymity. Once the questionnaires had been collected and the answers analyzed, the results of the first round were passed on to the participants, who receive the identified concepts in order of greater or lesser importance according to the group; this constituted the main part of the second questionnaire. It was necessary to make certain adjustments, because in the source literature there were anachronistic denominations of the same concept (and from now on they will appear in the same item), and also because there was ambiguity in several cases. Some concepts were dismissed because experts rejected them, and several concepts from the study Concept inventory for Engineering Graphics were incorporated. The second questionnaire was administered and carried out analogously to the first one two months later.

\subsubsection{Measuring consensus}

The degree of consensus is defined by the number of participants who have identified the concept. We establish four sections, and if at least three participants have accepted the concept we consider it to be "identified" (Table 1).

Table 1: Terms that define the degree of consensus

\begin{tabular}{ll}
\hline \hline Term & Participants that accept \\
\hline Full consensus & All participants (5) identify the concept \\
Very good consensus & At least 4 participants identify the concept \\
Good consensus & At least 3 participants identify the concept \\
Some consensus & 1 or 2 participants identify in consensus \\
Without consensus & No participant identifies the concept \\
\hline
\end{tabular}

\subsubsection{Measuring importance assigned to the concept}

We quantify the degree of consensus regarding the importance assigned to the concept among the concepts identified, by at least three experts (Table 2).

Table 2: Terms that define the importance assigned

\begin{tabular}{ll}
\hline \hline Importance & Average \\
\hline Very important & Media 5 \\
Important & Media $\geq 4$ \\
Slightly important & Media $\geq 3$ \\
Less important & Media $\geq 2$ \\
Without importance & $0 \geq$ Media $\geq 1$ \\
\hline
\end{tabular}




\section{$2.2 \quad$ Student survey}

Out of the Delphi process and related with it, this process produces additional information deriving from a comparison of experts' and students' opinions. As the final objective of this process is to design a pedagogical cognitive tool, it must include these identified concepts to successfully fulfil the task of satisfying users' needs, initially in the academic context and probably in the professional one at a later date. The fundamental concepts are considered either because of their difficulty or due to their importance within the field of knowledge; here both experts and students have something to contribute. Currently, the students are doing an industrial engineering degree at the School of Industrial Engineering (Escuela de Ingenierías Industriales (EII)) at the University of Valladolid $(U V a)$. We must remember that they are involved in a broad spectrum of technical studies (not only in the graphic field). They are taught engineering graphic subjects in their first, third and fifth semesters, respectively. They were invited to answer the questionnaire if they wished. We made the second Delphi survey (Figure 5) accessible to these students at the university online campus for three weeks, and we obtained eighty-six answers. A comparative study of, and subsequent reflection on, the difficulty assigned by the experts and students is summarized in the next section.

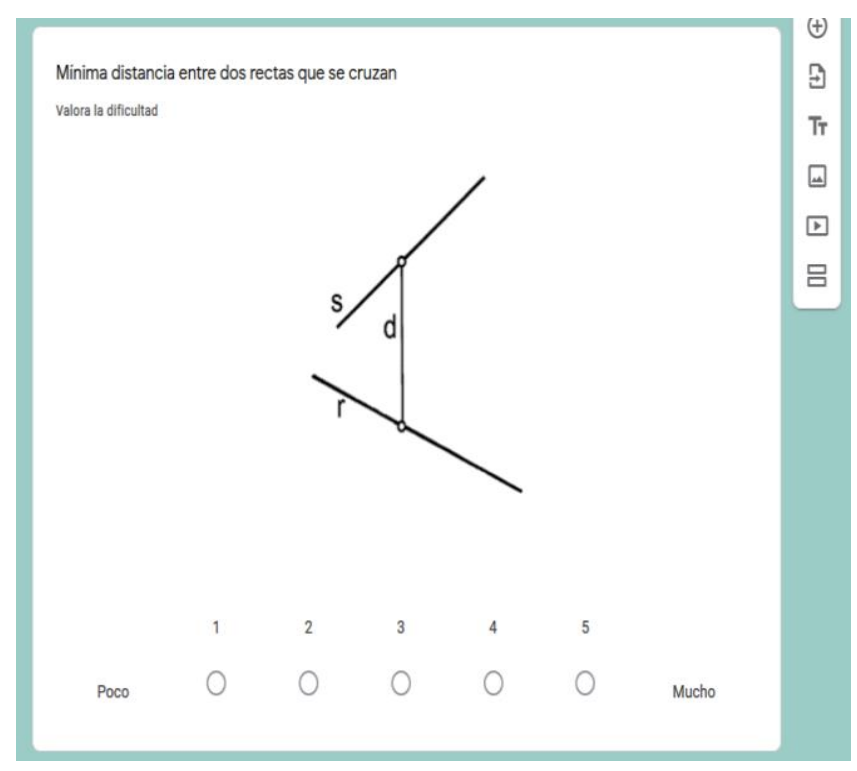

Figure 5: Minimum distance between two lines that cross (without intersection). Example of online survey accessible at the moment in (https://docs. google.com/forms/d/1jj-cYVLXSCgipRPzxShSIAX1QxAURW4vseq fB0Zd5V4/edit?ts=5dd2590a) 


\section{Results}

We present the concepts identified by the experts (three is the minimum number of experts required to accept a concept); these answers constitute the results of the first round. Experts again give their opinion so that they can reaffirm their initial assessment, but this time on a document in which the concepts appear in order of importance decided on by the group; such responses represent the results of the second round. Finally, we present a comparison of the opinions of experts and students regarding the difficulty of these concepts.

\subsection{First round results}

Appendix 1 shows the seventy concepts that at least three experts have accepted; they show an average greater than 4 in terms of importance (1 is of little importance and 5 is very important). It also shows their degree of difficulty.

\subsection{Second round results}

In the second round we present, in Appendix 2, the previously identified and ordered sixty-seven concepts of greater or lesser importance in the opinion of the group; the different denominations corresponding to the same concept have been unified, with the incorporation of some of the concepts of graphic engineering that were considered for Engineering Graphics Concepts: A Delphi Study (Sadowski and Sorby 2015), and which are suitable for our target user. In order to identify and quantify the level of consensus among experts on a series of concepts belonging to the field of graphic expression in engineering, we compare the results from both stages (Appendix 3) and establish a high degree of consensus, namely, a difference of less than or equal to 0.2 points; as a result, we obtain an initial list of concepts obtained by a consensus of experts. Table 3 summarizes the final statement of 20 concepts agreed on by the experts together with their ratings. Note that in table 3 , the concepts are ordered from highest to lowest importance in round II. This should be the case since this second questionnaire is definitive because the experts reaffirm and highlight their opinion when necessary. 
Table 3: Consent concepts by experts

\begin{tabular}{|c|c|c|}
\hline Concept & $\begin{array}{l}\text { Importance } \\
\text { Round I }\end{array}$ & $\begin{array}{l}\text { Importance } \\
\text { Round II }\end{array}$ \\
\hline 1. Acotar & 5 & 5 \\
\hline 2. Seguir las normas / Normalizado & 5 & 4,8 \\
\hline 3. Elección de las vistas & 4,8 & 4,8 \\
\hline 4. Rectas horizontales de plano & 4,8 & 4,8 \\
\hline 5. Rectas frontales de plano & 4,8 & 4,8 \\
\hline 6. Posición relativa de las vistas & 4,71 & 4,6 \\
\hline 7. Teorema de las tres perpendiculares & 4,6 & 4,6 \\
\hline 8. Método de proyección del primer diedro & 4,4 & 4,6 \\
\hline 9. Corte / corte por un plano & 4,3 & 4,4 \\
\hline 10. Disposición de los cortes & 4,6 & 4,4 \\
\hline 11. Línea fina de trazos y puntos & 4,4 & 4,4 \\
\hline 12. Rayado de diferentes partes cortadas de una misma pieza & 4,4 & 4,4 \\
\hline 13. Recta perpendicular a un plano & 4,4 & 4,4 \\
\hline 14. Corte en ángulo / Corte por dos planos concurrentes & 4,4 & 4,3 \\
\hline 15. Disposición normalizada de las vistas / Seis vistas normalizadas & 4,25 & 4,2 \\
\hline 16. Corte de nervios, elementos de fijación, árboles, radios de ruedas y otros elementos análogos & 4,4 & 4,2 \\
\hline 17. Identificar el plano de corte & 4,33 & 4,2 \\
\hline 18. Sección abatida / sección transversal & 4,2 & 4 \\
\hline 19. Línea fina de trazos & 4,2 & 4 \\
\hline 20. Línea de máxima inclinación de un plano & 4,2 & 4 \\
\hline
\end{tabular}

\subsection{Students' assessment}

A version of the second survey had been digitally sent and eighty-six students freely chose to fill in the questionnaire. This allowed us to identify the concepts that involved some degree of difficulty and that resulted in a cognitive need that could be satisfied. The minimum difficulty value assigned is 1.65 and the maximum is 3.45 (1 to 5). It should be noted that of the 20 concepts lower level of difficulty, 18 correspond to the same UNE 1032 standard (ISO 128) which is studied in class since the very first day. This reinforces our opinion that the direct teacher-student relationship is positive. Abstract concepts and those requiring a working method are perceived as having a higher degree of difficulty. See Appendix 4 for the results.

Likewise, being able to compare the (expert) teacher's point of view with that of the student allows us to draw conclusions regarding both convergence and divergence on perceived concept difficulty. 


\subsection{Experts and the concepts of Sadowski and Sorby's study}

The experts acknowledge the concepts proposed deriving from the work of Sadowski and Sorby. These are the last fourteen concepts in Appendix 2 and their importance is rated between 3.5 and 5 .

\section{Discussion}

As a result of the Delphi process, an initial list of concepts is obtained. This list will be the starting point for further decisions affecting the configuration of the dictionary and to attain our objectives:

(i) We have an initial lemma list

(ii) The data structure must be configured

(iii) We suggest precise definitions adapted to the user

(iv) We analyze the rating when appreciating the difficulty of some concepts

\subsection{The initial lemma list}

The initial lemma list includes twenty concepts suitable for intermediate students of industrial engineering, and which can fulfil their information needs. This list initiates a process to visualize graphic engineering concepts in terms, on the one hand, of the verbal part for future engineers and, on the other, of the graphical part for lexicographers. Each concept may increase the initial lemma lpst with both verbal lemmas and graphic lemmas (see our entry for acotar below).

There are twenty concepts agreed on by the experts (listed in the Results section) from a set of seventy-one identified and accepted in the process we have carried out. The initial lemma list consists of twenty concepts and, with the exception of one, all are multi-word lexical items. This contradicts the structure and format of many traditional dictionaries, but is in line with current research on specialized lexicography (Fuertes-Olivera and Tarp 2014).

We firmly believe that we can use the Delphi method to augment an essential list of concepts in any other sub-field of graphic engineering, whilst ensuring that the needs of a particular user of a specialized dictionary are met. In addition, the second questionnaire is available on the university's digital services and can be reused in the future.

\subsection{Configuration of the data structure}

We determined the data structure for organizing pieces of information in order to satisfy user' needs and to provide an efficient repository with access functions. When determining the functions of the dictionary, it is necessary to con- 
sider the visual reference, the structure and functions of the graphic representation and its functional relationship with the lexical part with which is complemented. We must account some considerations regarding the data storage structure and the data presentation structure:

- The data storage structure must be a lexicographic record that has a template format organized in fields that houses lexical and graphic units that must be labelled together (whenever possible).

- The data presentation structure must be appropriate for each level of complexity and present simultaneously a verbal component and an associated graphic component (up to an advanced level). At the initiation level in EGI, both components are simple and direct textually and graphically. At an intermediate level both components are complex, so they include previous reformulations. At an advanced level there is only a graphic component or the textual component would be minimal (it would be very complex, imprecise, and incomplete to lexicalize certain geometric concepts or to lexicalize to precisely define an object to be mass-produced).

Studies on specialized lexicographic need to address the data fields that we propose to be linked to the types of information required (Fathi 2014). We have included them in three blocks for each concept: grammatical information, meaning, and graphic representation. Grammatical information include collocations, lexical relationships (antonyms, synonyms etc.) and a domain label. Meaning describes as accurately as possible the concept given in literature definitions, duly standardized, by authors of accredited prestige, before our proposed definition was given. Graphic representation includes standardized forms and examples of practical application.

The example of the concept "acotar" (dimensioning) shows how we have organized the data structure in the abovementioned three sections, each of which contains subsections:

Concept: acotar (dimensioning) (each "collocation" and 'inflexions' can be also included as lexical and/or graphic lemmas in future developments of the online dictionary. Hence, each basic or fundamental concept may result in more than 100 different lemmas in the proposed dictionary)

1. Grammatical information

Word class: Verbo (verb)

Inflexions: acotación, cota, acotado

Collocations grouped by domain label: Dibujos técnicos. ACOTACIÓN: acotación funcional directa; acotación funcional indirecta; elementos de acotación; método de acotación; acotación de radios; acotación de cotas superpuestas; acotación en serie; acotación a partir de un elemento en común; acotación en paralelo; acotación por coordenadas; acotación combinada; acotación de elementos equidistantes dispuestos linealmente a intervalos; acotación de elementos equidistantes 
dispuestos angularmente a intervalos; acotación simplificada de chaflanes; acotación de conjuntos; acotación de las tolerancias; cota; cota funcional; cota no funcional; cota auxiliar; cota lineal; cota angular; cifra de cota; línea auxiliar de cota; línea de cota; cotas superpuestas; líneas de cota oblicuas; cifras de cotas angulares; cota fuera de escala; simbolo que precede la cifra de cota; disposición de las cotas; cadenas de cotas; línea de cota del radio; cota angular; cota de altitud; cota de nivel Dibujos técnicos. Tolerancias de cotas lineales y angulares: cota con tolerancia; cota nominal; cota superior; cota inferior; cota con límite superior; cota con limite inferior; cota del agujero; cota del eje

Dibujos técnicos. Tolerancias de cotas lineales y angulares: cota con tolerancia; cota nominal; cota superior; cota inferior; cota con límite superior; cota con limite inferior; cota del agujero; cota del eje

Especificaciones geométricas de producto (GPS). Acotado geométrico: acotado geométrico; acotación geométrica; acotación geométrica de piezas; elemento geométrico acotado; cilindro acotado; superficie media acotada; característica a acotar; figuras acotadas

Dibujos técnicos. Métodos de proyección. Parte 3: Representaciones axonométricas: acotados

Dibujos técnicos. Roscas y piezas roscadas: Acotación de piezas roscadas, acotar la longitud del roscado, acotar la profundidad del agujero ciego

\section{Meaning}

Definitions by authors of accredited prestige and standardized ones:

a. señalar las magnitudes que determinan la geometría o características geométricas de un objeto atendiendo a aspectos tales como funcionamiento, fabricación, montaje o verificación de las magnitudes (A. Valin)

b. el proceso de situar las medidas de la pieza sobre el plano, y los elementos que reflejan las medidas reales de la pieza se denominan cotas (Félez and Martínez 2008)

c. acotar es dimensionar, las dimensiones y notas describen el tamaño, el terminado y otros procesos de fabricación en el dibujo, de tal forma que el objeto quede total y precisamente definido. Las dimensiones describen el tamaño y la ubicación de los elementos de un objeto (Giesecke et al. 2016)

d. (De «cota», número.) Poner números o cotas en un plano (Moliner and Moliner 1998)

Our proposed definition:

e. proceso de consignar sobre la representación de un objeto sus dimensiones reales, definiendo con precisión el tamaño, la ubicación y la geometría (si fuera necesario) teniendo en cuenta el proceso de fabricación y las recomendaciones normalizadas de la representación 


\section{Graphic representations}

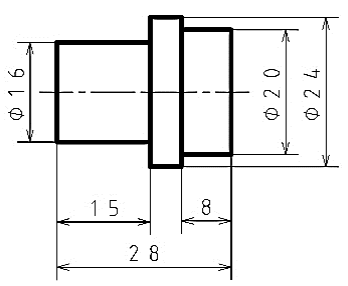

Figure 6: Examples of practical application The drawing precisely defines the geometry and dimensions of an object.

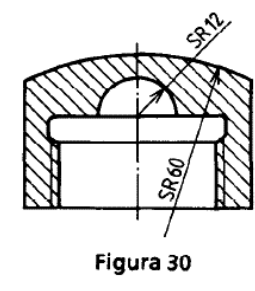

Figure 7: Standard representation UNE 1-039-94

\subsection{Deconstructing definitions}

We recommend precise definitions adapted to the user. This means adapting the definition to their needs and situation. This online dictionary has a defined data presentation template with the content located in a specific fixed place on the screen. The data access protocol is also defined and is clickable by user situation that corresponds to the function of the dictionary. There are adapted definitions of the same concept because we consider the possibility that the student needs previous knowledge to progress. In some cases, these adapted definitions are interpretations and in another, they are possible implications that a student at a training level is not able to assimilate initially. We start from the most abstract general definition and present definitions of simpler concepts that the student may need to review. All the details of this proposal are part of a doctoral thesis that will be defended in the coming months. The needs mentioned occur in an extra-lexicographic situation involving acquisition of technical principles where prior knowledge is required. According to the Function Theory of Lexicography, the context of acquiring technical knowledge is obviously that of cognitive situations. However, the purpose of the drawings used and the geometric elements involved refer unequivocally to operational (Figure 3) and interpretative (Figures 6,7) situations. We note, as an example, the concept acotar (dimensioning) and a proposed deconstructed definition in case some prior knowledge must be clarified or made accessible. The information we consider should be made accessible to the user, e.g. by clarifying its definition verbally and graphically, as shown below:

Acotar: proceso de consignar sobre la representación de un objeto sus dimensiones reales, definiendo con precisión el tamaño, la ubicación y la geometría (si fuera necesario) teniendo en cuenta el proceso de fabricación y las recomendaciones normalizadas para la representación

Dimensioning: the process of adding the true dimensions of an object on 
its representation, defining accurately size, location and geometry (if necessary) considering the manufacturing process and standardized recommendations of the representation

- consignar sobre la representación de un objeto (adding on the representation of an object), hace referencia por una parte a que se debe reservar un espacio para disponer las cotas, por otra, a que son necesarios ciertos elementos que sitúan y definen las cotas con precisión y finalmente a que la representación puede ser sobre una representación plana o una perspectiva

- consignar: destinar un lugar o sitio para poner o colocar en él algo (RAE 2014)

- dimensiones reales de un objeto, el objeto puede estar representado a escala por lo que los valores de las cotas han de ser los correspondientes al objeto real

- definir con precisión, hace referencia por una parte que debemos limitar las líneas de cota al elemento geométrico y por otra parte que debemos acotar sin ambigüedad lo que implica no dar información dimensional que pueda conducir a una indeterminación de la geometría

- definir el tamaño implica definir los elementos geométricos que conforman el objeto y sus características $y$, conocer de antemano las cotas necesarias para definir el objeto

- definir la ubicación de los elementos geométricos y de sus relaciones entre sí

- puede ser necesario definir, aclarar, precisar la geometría; se refiere a los símbolos que preceden a la cifra de cota y que "permiten la identificación de las formas y mejoran la interpretación del dibujo" (UNE 1-039)

- elegimos las dimensiones con aplicación directa en la fabricación del objeto, no las que son consecuencia del proceso de fabricación

- las pautas para consignar las dimensiones y los elementos que intervienen en la acotación de un objeto sobre su representación está(n) especificado(s) en distintas Normas

Figure 8 shows, as an example, the data proposal when starting a query with the 'acotar' key according to the interpretative function. The basic dictionary template model is organized into blocks containing: the lemma (key) or concept and its lexical family; the associated graphic representation; grammatical information (if necessary); function and definitions or descriptions (depending on the function).

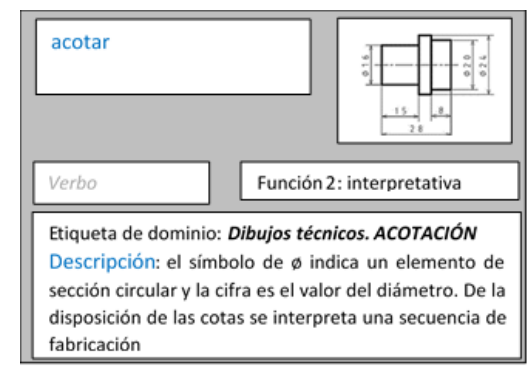

Figure 8: Acotar key, interpretative function 
From a quantitative perspective, the election of the concept 'acotar' is justified as an example. As a result of the Delphi method, this concept was identified by all the experts in questionnaire I, with an average importance of 5 and an average difficulty of 4.5 , and the same results were obtained in questionnaire II. This reaffirms the initial opinion and consolidates a full consensus of the group of experts. In addition to our findings we have the results of research by Sadowski and Sorby (2015), the concept 'dimensioning' occupies position 9 of 39 in the Concept inventory for Engineering Graphics.

\subsection{Rating of the concepts according to their difficulty}

We analyze the rating when appreciating the difficulty of some concepts by contrasting the opinion of six experts and eighty-six students regarding 52 concepts (see Appendix 5). In the graph (see Figure 9) we can observe the trends, convergences, divergences and rating of both in absolute terms.

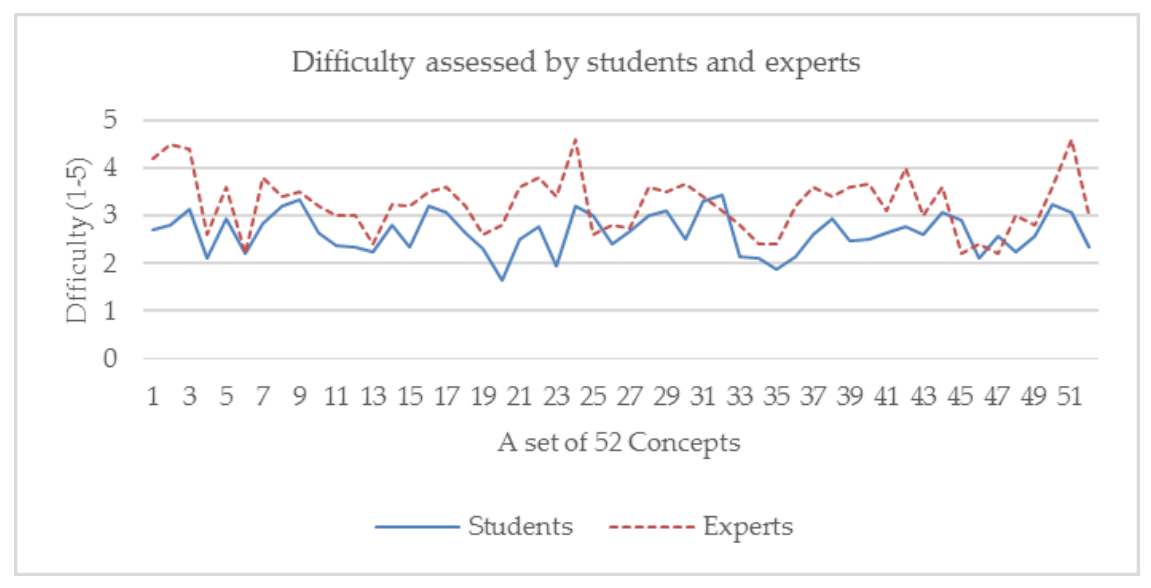

Figure 9: Difficulty assessed by students and experts with regard to 52 concepts The dotted line represents the opinion of the experts and the solid line the opinion of the students.

A relevant finding when we first look at the graph is that the experts generally assign greater difficulty values to the concepts than the students. However, they concur on six concepts and a certain parallelism is appreciated in both lines. Next, we observe a greater oscillation in the rating of concepts by experts compared to that in the case of students. An explanation of why experts appreciate a greater difficulty regarding concepts is related to their proficient understanding of these and their bearing in mind the implications and the external and internal references. However, in the case of students, there is less oscillation in the rating given to the concepts. In a learning process, with contact, as in 
this case, between teachers and students, the difficulties presented by the concepts are exposed and resolved, so the degree of difficulty is lower and the perception is more homogeneous.

Both concur when assessing the following concepts: 6 linea llena gruesa (continuous wide line ISO 128-24); 9 corte longitudinal de una forma de revolución (que contiene detalles regularmente repartidos no situados en el plano de corte y siempre que no se produzca ambigüedad); $\mathbf{1 3}$ corte total o corte por un plano; 27 Disposición normalizada; 31 corte en ángulo o corte por dos planos concurrentes and 49 representación de elementos repetitivos.

The most prominent divergences appear in the following concepts: $25 \mathrm{seg}-$ mento paralelo a un plano coordenado; 32 Sección múltiple abatida o disposición de las secciones sucesivas; 45 indicación del método de proyección and 47 Interrupción del rayado. Earlier, we mentioned that the expert recognizes the external implications of a concept which is more complex. For example, in concept 32, an expert is aware that an object can also be sectioned by a conical and cylindrical surface, whereas a student's initial approach would probably be to expect a flat surface.

It is worth highlighting the concepts that experts perceive as involving greater difficultly and those which are more difficult for students (four from those of expert assessment and eight from the students'). It should be noted that two concepts appear in both choices:

The concepts which, according to the experts, imply much greater difficulty vis-à-vis the other:

- 2. Acotar

- 3. Seguir las normas/normalizado

- 24. Teorema de las tres perpendiculares

- 51. Línea de máxima inclinación de un plano

The concepts which, in the opinion of the students, are considerably more difficult than the others:

- 3. Seguir las normas/normalizado

- 9. Corte longitudinal de una forma de revolución (que contiene detalles regularmente repartidos no situados en el plano de corte y siempre que no se produzca ambigüedad)

- 16. Planos no paralelos a los de proyección

- 24. Teorema de las tres perpendiculares

- 29. Rosca métrica

- 32. Sección múltiple abatida o disposición de las secciones sucesivas

- 44. Sección abatida o sección transversal

- 50. Segmento mínima distancia

We propose adding these concepts, in a second phase of the project, to the twenty concepts of the initial lemma list. This means adding six concepts to the initial list. These concepts are identified as numbers 9, 16, 29, 32, 34 and 50. 
Finally, we must cite the cases, hitherto unmentioned, in which the students assign greater difficulty to a concept than the experts: 25 segment paralelo a un plano coordenado; 45 Indicación del método de proyección; 47 interrupción del rayado. In fact, in these three cases the difficulty assigned by both students and experts is less than three. However, since there is a discrepancy we will ensure the inclusion of these elements in successive phases.

\section{Conclusion}

Specialized concepts require specialized codes for their definition and representation and, therefore, differentiated criteria are required to compile a specialized dictionary. This study concerns "an expert method endorsed by more experts", using the Delphi technique to identify and agree on an expert list of concepts that are not dealt with from a lexicographic point of view in the literature on EGI. We have been able to visualize certain concepts that students find slightly or considerably difficult, a factor which will probably hinder their learning. We believe that the difficult concepts, identified as such by experts and tested by students, must be included in our dictionary proposal in order to fulfil their cognitive needs.

We mainly, but not exclusively, propose, in line with the tenets of the Function Theory, a cognitive function dictionary (Bergenholtz and Nielsen 2006: 287) with online access. This will contain and present multimedia data on a specialized area of knowledge, involving both a verbal and a graphic component in coexistence, depending on operations relating to communication or enquiry. As "functions are the heart and soul of lexicography", it is understandable that lexicographic functions govern decisions about content, form, preparation and access to lexicographic data. Our proposal is for specialized lexicography and an online dictionary which is "multi-functional allowing for individualized data access" (Fuertes-Olivera and Tarp 2014: 62-64), as we have already mentioned (see Section 4.3.)

We believe that communicative, cognitive, operational and interpretive situations take place in a specialized learning context in the field of graphic engineering. All of them do not take place every time and at the same time, but it depends on the characteristics and needs of the users' and their situation. A general notion of graphic expression in engineering indicates that:

- a drawing (a projection of an idea or an object onto a plane) is a "message" that can avoid language barriers

- it deals with a process of acquiring practical knowledge for engineers

- to manufacture any single object, it must first have been graphically defined and drawn

- some of the drawings (iconic representation) shown in this study (figure 3 and 6) can and should be interpreted with the appropriate prior knowledge. 
In the near future, it may be necessary to expand the literary sources within the field of study (diedric system, axonometric system, UNE and ISO standardization), other fields within EGI (CAD) and extensively to Industrial Graphic Engineering. The structure defined for the data (grammatical information, meaning and graphic representation) in this study is applicable to all the dictionary entries with a verbal and graphic presentation for each of the collocations. It is possible and advisable to repeat the Delphi method with expert engineers and the questionnaire on the online campus with future students, thereby enlarging the results and content of the dictionary.

We believe that it will be necessary to explain the nature of the graphic component and the linguistic-graphic relationship for identifying and representing particular specialized knowledge in EGI. It is a fact that the domain of graphic engineering requires a complex cognitive process, and that the conceptual system underlying many of the mental operations in this area is also complex (cf. Kageura 1997: 119), these mental operations require geometric constructions with points, lines and surfaces. It is likely that future consultations on an online specialized dictionary can be made for graphic units that represent graphic concepts, ideas and objects.

\section{Acknowledgements}

We would like to express our gratitude to our colleagues, professors S. Alvarez, E. Reboto, Q. Rodríguez, A. Santos and A. Valin of the University of Valladolid $(U V a)$ for their honesty and for finding time between their teaching activity to cooperate in this work; to the students of EGI (Graphic Expression in Engineering) GIE (Electrical Engineering Degree) and GIM (Mechanical Engineering Degree), to the students of DAO (Computer Aided Design) at GIM and GIDIyDP (Industrial Design Engineering and Product Development) at the University of Valladolid, for their prompt and altruistic collaboration. We also thank two anonymous reviewers for the suggestions made to a previous draft of this paper.

\section{References}

\section{Dictionaries}

Moliner, M. and M. Moliner. 1998. Diccionario de uso del español. Vol. 2. Madrid: Gredos.

Real Academia Española. 2014. Diccionario de la lengua española. 23rd edition, [versión 23.3 en línea]. $<$ https://dle.rae.es> [Last accessed: July, 2, 2020].

\section{Other Literature}

Álvarez Garrote, S., E. Reboto Rodríguez, Q. Rodríguez Ovejero and M. Escribano Negueruela. 2018. Prácticas de Expresión Gráfica III. Valladolid: Los autores. 
Arias, A.M., M. de la Torre and M.I. Fijo. 2013. ICTIOTERM: Base de datos terminológicos y de identificación de especies pesqueras de las costas de Cádiz y Huelva. Available at: http://www.ictioterm.es/ proyecto_ictioterm.php [Last accessed: August, 21, 2020].

Bergenholtz, H. and S. Nielsen. 2006. Subject-field Components as Integrated Parts of LSP Dictionaries. Terminology. International Journal of Theoretical and Applied Issues in Specialized Communication 12(2): 281-303.

Bergenholtz, H. and S. Tarp. 2003. Two Opposing Theories. On H.E. Wiegand's Recent Discovery of Lexicographic Functions. HERMES. Journal of Linguistics 31: 171-196.

Bowker, L. and J. Pearson. 2002. Working with Specialized Language. A Practical Guide to Using Corpora. London/New York: Routledge.

Čermák, F. 2003. Source Materials for Dictionaries. Van Sterkenburg, Piet (Ed.). 2003. A Practical Guide to Lexicography: 18-25. Amsterdam/Philadelphia: John Benjamins.

Comité técnico AENOR. 1982. Norma UNE 1-032-82 (ISO 128). Dibujos técnicos. Principios generales de representación. Madrid: AENOR.

Comité técnico AENOR. 1994. Norma UNE 1-039-94. Dibujos técnicos. Acotación. Principios generales definiciones, métodos de ejecución e indicaciones especiales. Madrid: AENOR.

Czinkota, M.R. and I.A. Ronkainen. 1997. International Business and Trade in the Next Decade: Report from a Delphi Study. Journal of International Business Studies 28(4): 827-844.

Fathi, B. 2014. Experts and Specialised Lexicography: Perspectives and Needs. Terminàlia 9: 12-21.

Félez, J. and M.L. Martinez. 2008. Ingeniería gráfica y diseño. Madrid: Editorial Síntesis.

Flume, P.A., P.J. Mogayzel Jr., K.A. Robinson, R. Rosenblatt, L., Quittell and B.C. Marshall. 2010. Cystic Fibrosis Pulmonary Guidelines: Pulmonary Complications: Hemoptysis and Pneumothorax. American Journal of Respiratory and Critical Care Medicine 182(3): 298-306.

Fuertes-Olivera, P.A. and H. Bergenholtz (Eds.). 2011. e-Lexicography: The Internet, Digital Initiatives and Lexicography. London/New York: Continuum.

Fuertes-Olivera, P.A. and H. Bergenholtz. 2018. Diccionario Español de Definiciones. Círculo de Lingüística Aplicada a la Comunicación 74: 169-194.

Fuertes-Olivera, P. A. and S. Tarp. 2014. Theory and Practice of Specialised Online Dictionaries: Lexicography versus Terminography. Berlin/Boston: De Gruyter.

Giesecke, F.E., A. Mitchell, H. Spencer, I. Hill, J. Dygdon and J. Novak. 2016. Technical Drawing with Engineering Graphics: 478. Boston: Prentice Hall.

Goetsch, D.L., W. Chalk and J.A. Nelson. 2000. Technical Drawing. Fourth edition. Albany/Boston: Delmar Publishers.

González García, V., R. López Poza and M. Nieto Oñate. 1982. Sistemas de representación. Sistema diédrico. Valladolid. Texgraf.

Hallowell, M.R. and J.A. Gambatese. 2010. Qualitative Research: Application of the Delphi Method to CEM Research. Journal of Construction Engineering and Management 136(1): 99-107.

Kageura, K. 1997. Multifaceted/Multidimensional Concept Systems. Wright, S.E. and G. Budin (Eds). 1997. Handbook of Terminology Management. Volume 1: Basic Aspects of Terminology Management: 119-132. Amsterdam: John Benjamins.

Linstone, H. and M. Turoff. 1975. The Delphi Method: Techniques and Applications. London: AddisonWesley.

Mason, J. 1996. Qualitative Researching. Thousand Oaks, USA: Sage Publications. 
Mason, J. 2002. Linking Qualitative and Quantitative Data Analysis. Bryman, A. and R.G. Burgess (Eds.). 2002. Analyzing Qualitative Data: 103-124. London: Routledge.

Nieto Oñate, M., V. González García and R. López Poza. 1970. Prácticas programadas de Dibujo Técnico. Delineantes industriales. Valladolid: DITEC.

Pérez Hernández, C., A. Moreno Ortiz and P. Faber Benítez. 1999. Lexicografía computacional y lexicografía de corpus. Revista Española de Lingüística Aplicada 1: 175-214.

Pinnis, M., T. Gornostay, R. Skadiňš and A. Vasiljjevs. 2013. Online Platform for Extracting, Managing, and Utilising Multilingual Terminology. Kosem, I. et al. 2013. Electronic Lexicography in the 21st Century: Thinking outside the Paper. Proceedings of the Third Biennial Conference on Electronic Lexicography, eLex 2013, Tallin, Estonia, 17-19 October, 2013: 122-131. Ljubljana/ Tallinn: Institute for Applied Slovene Studies/Eesti Keele Instituut.

Powell, C. 2003. The Delphi Technique: Myths and Realities. Journal of Advanced Nursing 41(4): 376382.

Rowe, G. and G. Wright. 1999. The Delphi Technique as a Forecasting Tool: Issues and Analysis. International Journal of Forecasting 15(4): 353-375.

Sadowski, M.A. and S.A. Sorby. 2015. Engineering Graphics Concepts: A Delphi Study. Paper presented at 2015 ASEE Annual Conference \& Exposition, Seattle, Washington, 14-17 June 2015. DOI: $10.18260 /$ p.23965.

Tarp, S. 2008. Lexicography in the Borderland between Knowledge and Non-knowledge: General Lexicographical Theory with Particular Focus on Learner's Lexicography. Tubingen: Niemeyer.

Tarp, S. 2009. Beyond Lexicography: New Visions and Challenges in the Information Age. Bergenholtz, H., S. Nielsen and S. Tarp (Eds.) 2009. Lexicography at a Crossroads. Dictionaries and Encyclopaedias Today, Lexicographical Tools Tomorrow: 17-32. Bern: Peter Lang.

Verlinde, S. and T. Selva. 2009. Corpus-based versus Intuition-based Lexicography: Defining a Word List for a French Learners' Dictionary. Coach 83: 1424. 
Appendix 1: Results of the first round of the Delphi method including the degree of consensus

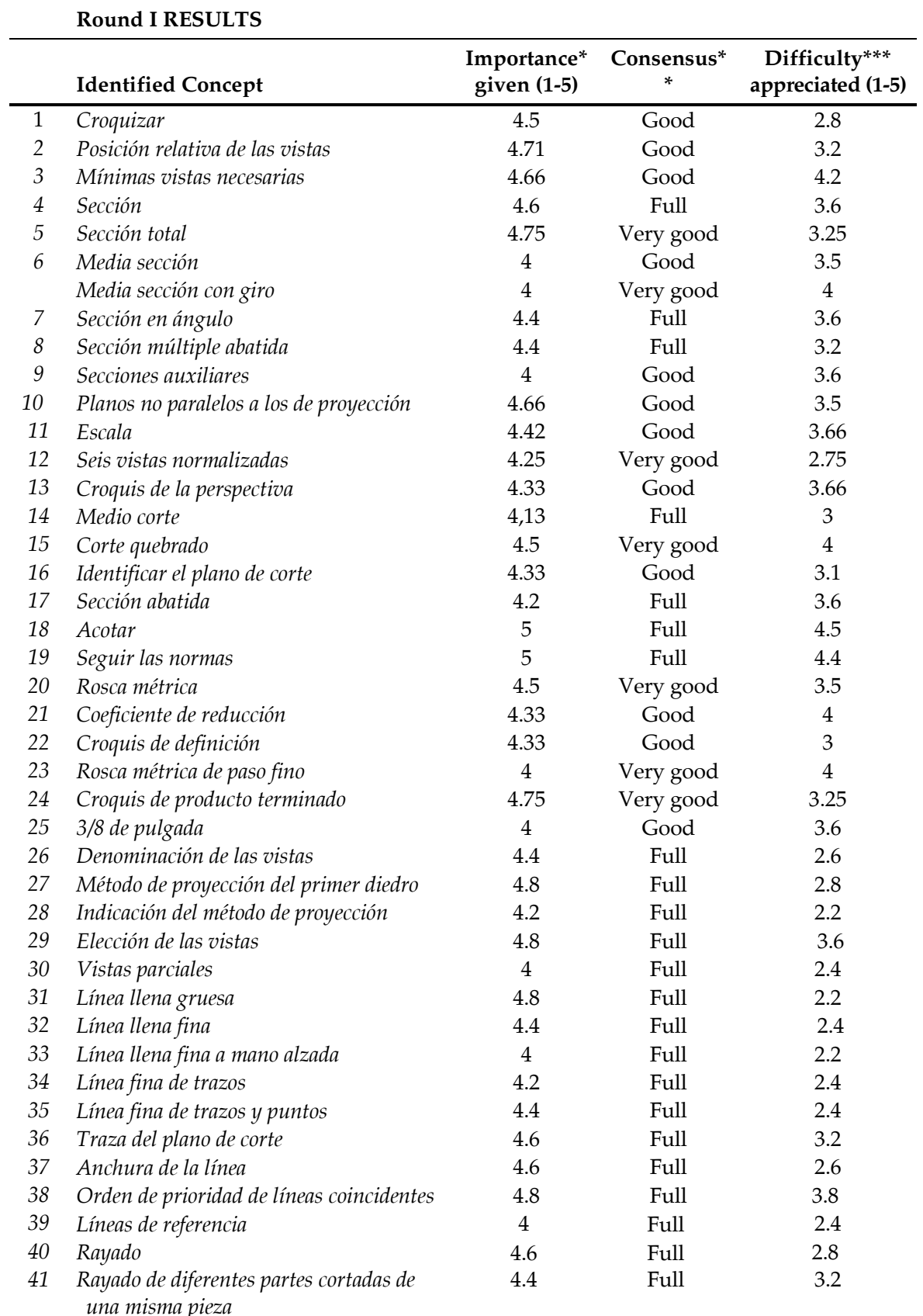


42 Interrupción de rayado

43 Corte

44 Plano de corte

45 Disposición de los cortes

46 Localización del plano de corte

47 Corte de nervios, elementos de fijación, árboles, radios de ruedas y otros elementos análogos

48 Corte por un plano

49 Corte por dos planos paralelos

50 Corte por planos sucesivos

51 Corte por dos planos concurrentes

52 Corte longitudinal de una forma de revolución que contiene detalles regularmente repartidos y no situados en el plano de corte, y siempre que no se produzca ambigüedad

53 Secciones abatidas con desplazamiento

54 Secciones abatidas sin desplazamiento

55 Corte local

56 Disposición de las secciones sucesivas

57 Vistas interrumpidas

58 Representación de elementos repetitivos

59 Detalles representados a escala mayor

60 Minima distancia entre dos rectas que se cruzan

61 Recta perpendicular a un plano

62 Teorema de las tres perpendiculares

63 Segmento mínima distancia

64 Segmento paralelo a un plano coordenado

65 Verdadera magnitud de un segmento a partir de sus proyecciones

66 Ángulo recta-plano

67 Rectas horizontales de plano

68 Rectas frontales de plano

69 Línea de máxima pendiente de un plano

70 Línea de máxima inclinación de un plano
4.8

4.6

4.6

4.6

4.4

Full

Full

Full

Full

Full

Full

Full

Full

Full

Full

Full

\section{2}

3.4

3.6

3.8

3.4

3.6

$\begin{array}{lll}4.4 & \text { Full } & 2.4\end{array}$

3.2

* The Importance given (from 1 to 5 ) is the criterion for belonging to the initial lemma list.

** The Consensus is considered if at least three panelists identity that concept

*** The Difficulty appreciated (from 1 to 5 ) permits a comparison of two points of view: those of experts and students. 
Appendix 2: Results of the second round of the Delphi method

\section{Round II RESULTS}

\begin{tabular}{|c|c|c|}
\hline & Concept & $\begin{array}{l}\text { Importance } \\
\text { given (1-5) }\end{array}$ \\
\hline 1 & Vistas suficientes / Minimas vistas necesarias / Vistas necesarias para definir ... & 4,8 \\
\hline 2 & Acotar & 5 \\
\hline 3 & Seguir las normas / Normalizado & 4,8 \\
\hline 4 & Mecanizar superficies & 3.6 \\
\hline 5 & Denominación de las vistas & 4,4 \\
\hline 6 & Elección de las vistas & 4,8 \\
\hline 7 & Linea llena gruesa & 4,4 \\
\hline 8 & Orden de prioridad de líneas coincidentes & 4 \\
\hline 9 & Corte / corte por un plano & 4,4 \\
\hline 10 & $\begin{array}{l}\text { Corte longitudinal de una forma de revolución que contiene detalles regularmente } \\
\text { repartidos y no situados en el plano de corte, y siempre que no se produzca ambigüedad }\end{array}$ & 3,8 \\
\hline 11 & Verdadera magnitud de un segmento a partir de sus proyecciones & 4,4 \\
\hline 12 & Rectas horizontales de plano & 4,8 \\
\hline 13 & Rectas frontales de plano & 4,8 \\
\hline 14 & Corte total / Corte por un plano & 4,4 \\
\hline 15 & Croquis de producto terminado & 4,4 \\
\hline 16 & Posición relativa de las vistas & 4,6 \\
\hline 17 & Planos no paralelos a los de proyección & 4 \\
\hline 18 & Sección & 3,8 \\
\hline 19 & Traza del plano de corte & 4,2 \\
\hline 20 & Anchura de la línea & 3,8 \\
\hline 21 & Rayado & 4 \\
\hline 22 & Plano de corte & 4,2 \\
\hline 23 & Disposición de los cortes & 4,4 \\
\hline 24 & Localización del plano de corte & 4 \\
\hline 25 & Teorema de las tres perpendiculares & 4,6 \\
\hline 26 & Segmento paralelo a un plano coordenado & 4,4 \\
\hline 27 & Croquizar & 4,2 \\
\hline 28 & Disposición normalizada de las vistas / Seis vistas normalizadas & 4,2 \\
\hline 29 & Corte quebrado / Corte por planos sucesivos & 4,2 \\
\hline 30 & Rosca métrica & 4,2 \\
\hline 31 & Escala & 4,8 \\
\hline 32 & Corte en ángulo / Corte por dos planos concurrentes & 4,3 \\
\hline 33 & Sección múltiple abatida / Disposición de las secciones sucesivas & 4 \\
\hline 34 & Método de proyección del primer diedro & 4,6 \\
\hline 35 & Linea llena fina & 3,8 \\
\hline 36 & Linea fina de trazos y puntos & 4,4 \\
\hline 37 & Rayado de diferentes partes cortadas de una misma pieza & 4,4 \\
\hline 38 & Corte de nervios, elementos de fijación, árboles, radios de ruedas y otros elementos análogos & 4,2 \\
\hline 39 & Mínima distancia entre dos rectas que se cruzan & 3 \\
\hline 40 & Recta perpendicular a un plano & 4,4 \\
\hline 41 & Croquis de la perspectiva & 3,8 \\
\hline 42 & Identificar el plano de corte & 4,2 \\
\hline 43 & Coeficiente de reducción & 3,6 \\
\hline 44 & Croquis de definición & 5 \\
\hline
\end{tabular}


http://lexikos.journals.ac.za; https://doi.org/10.5788/30-1-1596

Selecting an Initial Lemma List in Specialized Lexicography

$\begin{array}{llc}45 & \text { Sección abatida / sección transversal } & 4 \\ 46 & \text { Indicación del método de proyección } & 3,4 \\ 47 & \text { Linea fina de trazos } & 4 \\ 48 & \text { Interrupción de rayado } & 3,4 \\ 49 & \text { Corte por dos planos paralelos } & 3,6 \\ 50 & \text { Representación de elementos repetitivos } & 3,8 \\ 51 & \text { Segmento mínima distancia } & 3,8 \\ 52 & \text { Línea de máxima inclinación de un plano } & 4 \\ 53 & \text { Medio corte o corte al cuarto } & 4,6 \\ 54 & \text { Plano de proyección } & 4,4 \\ 55 & \text { Plano de referencia } & 3,8 \\ 56 & \text { Plano Datum } & 3,5 \\ 57 & \text { Cota de situación } & 4,4 \\ 58 & \text { Ortogonal, perpendicular, normal } & 4,6 \\ 59 & \text { Plano representado por una línea, plano proyectante } & 4 \\ 60 & \text { Dirección y sentido de la visual / Linea (dirección) de observación } & 4,8 \\ 61 & \text { Verdadera forma } & 5 \\ 62 & \text { Verdadera dimensión-magnitud } & 5 \\ 63 & \text { Elemento de revolución } & 4 \\ 64 & \text { Alineamiento de las vistas } & 5 \\ 65 & \text { Perspectiva estallada } & 5 \\ 66 & \text { Proyección cilíndrica ortogonal / vistas ortogonales } & 5 \\ 67 & \text { Oblicuo / NO ortogonal } & 4,8\end{array}$


Appendix 3: Comparative summary of the importance perceived by the experts in round I and round II

\begin{tabular}{|c|c|c|c|}
\hline & Concept & Importance in round I & Importance in round II \\
\hline 1 & $\begin{array}{l}\text { Vistas suficientes / Mínimas vistas necesarias / } \\
\text { Vistas necesarias para definir ... }\end{array}$ & 4,8 & 4,8 \\
\hline 2 & Acotar & 5 & 5 \\
\hline 3 & Seguir las normas / Normalizado & 5 & 4,8 \\
\hline 5 & Denominación de las vistas & 4,8 & 4,4 \\
\hline 6 & Elección de las vistas & 4,8 & 4,8 \\
\hline 7 & Línea llena gruesa & 4,8 & 4,4 \\
\hline 8 & Orden de prioridad de líneas coincidentes & 4,8 & 4 \\
\hline 9 & Corte / corte por un plano & 4,3 & 4,4 \\
\hline 10 & $\begin{array}{l}\text { Corte longitudinal de una forma de revolución } \\
\text { que contiene detalles regularmente repartidos } \\
\text { y no situados en el plano de corte, y siempre } \\
\text { que no se produzca ambigüedad }\end{array}$ & 4,8 & 3,8 \\
\hline 11 & $\begin{array}{l}\text { Verdadera magnitud de un segmento a partir } \\
\text { de sus proyecciones }\end{array}$ & 4,8 & 4,4 \\
\hline 12 & Rectas horizontales de plano & 4,8 & 4,8 \\
\hline 13 & Rectas frontales de plano & 4,8 & 4,8 \\
\hline 15 & Croquis de producto terminado & 4,75 & 4,4 \\
\hline 16 & Posición relativa de las vistas & 4,71 & 4,6 \\
\hline 18 & Sección & 4,6 & 3,8 \\
\hline 19 & Traza del plano de corte & 4,6 & 4,2 \\
\hline 20 & Anchura de la linea & 4,6 & 3,8 \\
\hline 21 & Rayado & 4,6 & 4 \\
\hline 22 & Plano de corte & 4,6 & 4,2 \\
\hline 23 & Disposición de los cortes & 4,6 & 4,4 \\
\hline 24 & Localización del plano de corte & 4,6 & 4 \\
\hline 25 & Teorema de las tres perpendiculares & 4,6 & 4,6 \\
\hline 26 & Segmento paralelo a un plano coordenado & 4,6 & 4,4 \\
\hline 27 & Croquizar & 4,5 & 4,2 \\
\hline 28 & $\begin{array}{l}\text { Disposición normalizada de las vistas / Seis } \\
\text { vistas normalizadas }\end{array}$ & 4,25 & 4,2 \\
\hline 29 & Corte quebrado / Corte por planos sucesivos & 4,45 & 4,2 \\
\hline 30 & Rosca métrica & 4,5 & 4,2 \\
\hline 31 & Escala & 4,42 & 4,8 \\
\hline 32 & $\begin{array}{l}\text { Corte en ángulo / Corte por dos planos con- } \\
\text { currentes }\end{array}$ & 4,4 & 4,3 \\
\hline 33 & $\begin{array}{l}\text { Sección múltiple abatida / Disposición de las } \\
\text { secciones sucesivas }\end{array}$ & 4,4 & 4 \\
\hline 34 & Método de proyección del primer diedro & 4,4 & 4,6 \\
\hline 35 & Línea llena fina & 4,4 & 3,8 \\
\hline 36 & Linea fina de trazos y puntos & 4,4 & 4,4 \\
\hline 37 & $\begin{array}{l}\text { Rayado de diferentes partes cortadas de una } \\
\text { misma pieza }\end{array}$ & 4,4 & 4,4 \\
\hline 38 & $\begin{array}{l}\text { Corte de nervios, elementos de fijación, árboles, } \\
\text { radios de ruedas y otros elementos análogos }\end{array}$ & 4,4 & 4,2 \\
\hline 39 & Mínima distancia entre dos rectas que se cruzan & 4,3 & 3 \\
\hline 40 & Recta perpendicular a un plano & 4,4 & 4,4 \\
\hline
\end{tabular}


http://lexikos.journals.ac.za; https://doi.org/10.5788/30-1-1596

Selecting an Initial Lemma List in Specialized Lexicography

$4,2 \quad 3,4$

$4,2 \quad 3,4$

$4,2 \quad 3,6$

$4,2 \quad 3,8$

53 Línea de máxima inclinación de un plano

$4,2 \quad 3,8$

4,2


Appendix 4: Results of students' opinions

The students quantify the difficulty of the Delphi second round concepts

\begin{tabular}{|c|c|c|}
\hline & Concepts & Difficulty (1-5) \\
\hline 1 & $\begin{array}{l}\text { Vistas suficientes / Minimas vistas necesarias / Vistas necesarias } \\
\text { para definir }\end{array}$ & 2,70 \\
\hline 2 & Acotar & 2,80 \\
\hline 3 & Seguir las normas / Normalizado & 3,13 \\
\hline 4 & Mecanizar superficies & 3,22 \\
\hline 5 & Denominación de las vistas & 2,10 \\
\hline 6 & Elección de las vistas & 2,93 \\
\hline 7 & Línea llena gruesa & 2,20 \\
\hline 8 & Orden de prioridad de lineas coincidentes & 2,83 \\
\hline 9 & Corte & 3,20 \\
\hline 10 & $\begin{array}{l}\text { Corte longitudinal de una forma de revolución que contiene } \\
\text { detalles regularmente repartidos y no situados en el plano de } \\
\text { corte; y siempre que no se produzca ambigüedad }\end{array}$ & 3,34 \\
\hline 11 & Verdadera magnitud de un segmento a partir de sus proyecciones & 2,63 \\
\hline 12 & Rectas horizontales de plano & 2,37 \\
\hline 13 & Rectas frontales de plano & 2,33 \\
\hline 14 & Corte total / Corte por un plano & 2,25 \\
\hline 15 & Croquis de producto terminado & 2,79 \\
\hline 16 & Posición relativa de las vistas & 2,35 \\
\hline 17 & Planos no paralelos a los de proyección & 3,19 \\
\hline 18 & Sección & 3,06 \\
\hline 19 & Traza del plano de corte & 2,64 \\
\hline 20 & Anchura de la línea & 2,32 \\
\hline 21 & Rayado & 1,65 \\
\hline 22 & Plano de corte & 2,49 \\
\hline 23 & Disposición de los cortes & 2,78 \\
\hline 24 & Localización del plano de corte & 1,94 \\
\hline 25 & Teorema de las tres perpendiculares & 3,21 \\
\hline 26 & Segmento paralelo a un plano coordenado & 2,99 \\
\hline 27 & Croquizar & 2,40 \\
\hline 28 & Disposición normalizada & 2,67 \\
\hline 29 & Corte quebrado / Corte por planos sucesivos & 3,02 \\
\hline 30 & Rosca métrica & 3,11 \\
\hline 31 & Escala & 2,51 \\
\hline 32 & Corte en ángulo / Corte por dos planos concurrentes & 3,29 \\
\hline 33 & Sección múltiple abatida / Disposición de las secciones sucesivas & 3,43 \\
\hline 34 & Método de proyección del primer diedro & 2,15 \\
\hline 35 & Linea llena fina & 2,12 \\
\hline 36 & Linea fina de trazos y puntos & 1,86 \\
\hline 37 & Rayado de diferentes partes cortadas de una misma pieza & 2,14 \\
\hline 38 & $\begin{array}{l}\text { Corte de nervios; elementos de fijación; árboles; radios de ruedas y } \\
\text { otros elementos análogos }\end{array}$ & 2,60 \\
\hline 39 & Mínima distancia entre dos rectas que se cruzan & 2,93 \\
\hline 40 & Recta perpendicular a un plano & 2,46 \\
\hline 41 & Croquis de la perspectiva & 2,52 \\
\hline 42 & Identificar el plano de corte & 2,65 \\
\hline
\end{tabular}


http://lexikos.journals.ac.za; https://doi.org/10.5788/30-1-1596

Selecting an Initial Lemma List in Specialized Lexicography

Coeficiente de reducción

Croquis de definición

2,62

Sección abatida / sección transversal $\quad 3,08$

Indicación del método de proyección $\quad 2,90$

Linea fina de trazos $\quad 2,12$

Interrupción de rayado $\quad 2,57$

Corte por dos planos paralelos $\quad 2,25$

Representación de elementos repetitivos $\quad 2,57$

Segmento minima distancia $\quad 3,23$

Línea de máxima inclinación de un plano $\quad 3,07$

Medio corte o corte al cuarto $\quad 2,35$

Plano de proyección $\quad 2,45$

Plano de referencia $\quad 2,70$

Plano Datum (de medidas) $\quad 3,45$

Cota de situación $\quad 3,05$

Ortogonal; perpendicular; normal $\quad 2,52$

Plano representado por una linea; plano proyectante $\quad 2,87$

Dirección y sentido de la visual / Línea (dirección) de observación $\quad 2,80$

Verdadera forma 2,83

Verdadera dimensión $\quad 3,02$

Elemento de revolución $\quad 2,78$

Alineamiento de las vistas $\quad 2,59$

Perspectiva estallada $\quad 3,36$

Proyección cilíndrica ortogonal / vistas ortogonales $\quad 3,00$

Oblicuo / NO ortogonal $\quad 3,28$


Appendix 5: Comparison of the students' perceived difficulty and that of the experts

\begin{tabular}{|c|c|c|}
\hline Concepts & $\begin{array}{l}\text { Students } \\
\text { difficulty }\end{array}$ & $\begin{array}{l}\text { Experts } \\
\text { difficulty }\end{array}$ \\
\hline $\begin{array}{l}1 \text { Vistas suficientes / Minimas vistas necesarias / Vistas necesarias para } \\
\text { definir }\end{array}$ & 2,70 & 4,2 \\
\hline 2 Acotar & 2,80 & 4,5 \\
\hline 3 Seguir las normas / Normalizado & 3,13 & 4,4 \\
\hline 4 Denominación de las vistas & 2,10 & 2,6 \\
\hline 5 Elección de las vistas & 2,93 & 3,6 \\
\hline 6 Linea llena gruesa & 2,20 & 2,2 \\
\hline 7 Orden de prioridad de líneas coincidentes & 2,83 & 3,8 \\
\hline 8 Corte & 3,20 & 3,4 \\
\hline $\begin{array}{l}9 \text { Corte longitudinal de una forma de revolución que contiene detalles } \\
\text { regularmente repartidos y no situados en el plano de corte; y siempre } \\
\text { que no se produzca ambigüedad }\end{array}$ & 3,34 & 3,5 \\
\hline 10 Verdadera magnitud de un segmento a partir de sus proyecciones & 2,63 & 3,2 \\
\hline 11 Rectas horizontales de plano & 2,37 & 3 \\
\hline 12 Rectas frontales de plano & 2,33 & 3 \\
\hline 13 Corte total / Corte por un plano & 2,25 & 2,4 \\
\hline 14 Croquis de producto terminado & 2,79 & 3,25 \\
\hline 15 Posición relativa de las vistas & 2,35 & 3,2 \\
\hline 16 Planos no paralelos a los de proyección & 3,19 & 3,5 \\
\hline 17 Sección & 3,06 & 3,6 \\
\hline 18 Traza del plano de corte & 2,64 & 3,2 \\
\hline 19 Anchura de la línea & 2,32 & 2,6 \\
\hline 20 Rayado & 1,65 & 2,8 \\
\hline 21 Plano de corte & 2,49 & 3,6 \\
\hline 22 Disposición de los cortes & 2,78 & 3,8 \\
\hline 23 Localización del plano de corte & 1,94 & 3,4 \\
\hline 24 Teorema de las tres perpendiculares & 3,21 & 4,6 \\
\hline 25 Segmento paralelo a un plano coordenado & 2,99 & 2,6 \\
\hline 26 Croquizar & 2,40 & 2,8 \\
\hline 27 Disposición normalizada & 2,67 & 2,75 \\
\hline 28 Corte quebrado / Corte por planos sucesivos & 3,02 & 3,6 \\
\hline 29 Rosca métrica & 3,11 & 3,5 \\
\hline 30 Escala & 2,51 & 3,66 \\
\hline 31 Corte en ángulo / Corte por dos planos concurrentes & 3,29 & 3,4 \\
\hline 32 Sección múltiple abatida / Disposición de las secciones sucesivas & 3,43 & 3,1 \\
\hline 33 Método de proyección del primer diedro & 2,15 & 2,8 \\
\hline 34 Linea llena fina & 2,12 & 2,4 \\
\hline 35 Linea fina de trazos y puntos & 1,86 & 2,4 \\
\hline 36 Rayado de diferentes partes cortadas de una misma pieza & 2,14 & 3,2 \\
\hline $\begin{array}{l}37 \text { Corte de nervios; elementos de fijación; árboles; radios de ruedas y } \\
\text { otros elementos análogos }\end{array}$ & 2,60 & 3,6 \\
\hline 38 Mínima distancia entre dos rectas que se cruzan & 2,93 & 3,4 \\
\hline 39 Recta perpendicular a un plano & 2,46 & 3,6 \\
\hline 40 Croquis de la perspectiva & 2,52 & 3,66 \\
\hline 41 Identificar el plano de corte & 2,65 & 3,1 \\
\hline 42 Coeficiente de reducción & 2,76 & 4 \\
\hline 43 Croquis de definición & 2,62 & 3 \\
\hline 44 Sección abatida / sección transversal & 3,08 & 3,6 \\
\hline
\end{tabular}


http://lexikos.journals.ac.za; https://doi.org/10.5788/30-1-1596

Selecting an Initial Lemma List in Specialized Lexicography

45 Indicación del método de proyección

2,90

2,2

46 Línea fina de trazos

2,12

47 Interrupción de rayado

48 Corte por dos planos paralelos

$2,57 \quad 2,2$

49 Representación de elementos repetitivos

2,25

2,57

50 Segmento minima distancia

$3,23-3,6$

51 Línea de máxima inclinación de un plano

3,07

52 Medio corte o corte al cuarto

2,35

2,4

3

2,8

3,6

4,6 